\title{
Prediction of quality attributes and maturity classification of pear fruit using laser imaging and Artificial Neural Network
}

\author{
1,*Adebayo, S.E. and ${ }^{2}$ Hashim, N. \\ ${ }^{I}$ Department of Agricultural and Bioresources Engineering, Federal University of Technology, Minna, \\ Nigeria \\ ${ }^{2}$ Department of Biological and Agricultural Engineering, Faculty of Engineering, Universiti Putra \\ Malaysia, 43400 UPM, Serdang, Selangor, Malaysia
}

\author{
Article history: \\ Received: 14 April 2020 \\ Received in revised form: 13 \\ August 2020 \\ Accepted: 6 December 2020 \\ Available Online: 27 \\ February 2021
}

\section{Keywords:}

Laser imaging,

Maturity stages,

Quality attributes,

Pear,

Optical properties

DOI:

https://doi.org/10.26656/fr.2017.5(S1).022

\begin{abstract}
In this study, the application of laser imaging technique was utilized to predict the quality attributes (firmness and soluble solids content) of pear fruit and to classify the maturity stages of the fruit harvested at different days after full bloom (dafb). Laser imaging system emitting at visible and near infra-red region $(532,660,785,830$ and $1060 \mathrm{~nm}$ ) was deployed to capture the images of the fruit. Optical properties (absorption $\mathrm{m}_{\mathrm{a}}$ and reduced scattering $\mathrm{m}_{\mathrm{s}}{ }^{\prime}$ coefficients) at individual and combined wavelengths of the laser images of the fruit were used in the prediction and classifications of the maturity stages. Artificial neural network (ANN) was employed in the building of both prediction and classification models. Root mean square error of calibration (RMSEC), root mean square error of crossvalidation (RMSECV), correlation coefficient $(r)$ and bias were used to test the performance of the prediction models while sensitivity and specificity were used to evaluate the classification models. The results showed that there was a very strong correlation between the $\mathrm{m}_{\mathrm{a}}$ and $\mathrm{m}_{\mathrm{s}}{ }^{\prime}$ with pear development. This study had shown that optical properties of pears with ANN as prediction and classification models can be employed to both predict quality parameters of pear and classify pear into different (dafb) non-destructively.
\end{abstract}

\section{Introduction}

Historically, quantification of fruit qualities relied on various destructive techniques that require the removal of a little quantity of fruit tissue and juicing for the measurement of SSC, total acidity, and nutritional content (Hoehn et al., 2003; Liu et al., 2010; Wold et al., 2004). These techniques resulted in a large amount of postharvest losses and inability to measure the whole batch as few samples from the batches are used for the measurement, which it also involves more man-hours to carry them out.

Human evaluation remains the most widely used method of fruit quality assessment. However, it has been established, that as a result of disparity in colour prejudice between individuals, eye fatigue, personal bias, lack of colour memory, and different lighting conditions often resulted in varying assessments. These factors have limited use of human evaluation to produce on a large scale universally accepted standard and for a broader spectrum of operation. Furthermore, the human eye is limited within the visible range band of the electromagnetic spectrum (400 to $700 \mathrm{~nm}$ ), coupled with the fact that certain quality attributes are only detectable outside of the visible band. This has made human evaluation not capable enough for fruit quality attribute determinations. As a result of this situation, a lot of work has been focused on the development of instruments responsive to an expansive band of electromagnetic spectrum and building fruits quality indices. Moreover, the non-destructive features of optical techniques have allowed them to be practically engaged in online fruit quality assessment. Optical techniques utilise ultraviolet, visible, near-infrared, infrared, and x-ray radiations of the electromagnetic spectrum.

Soluble solids content (SSC) is one of the internal quality indicators in most fruit. SSC is a refractometric index which expresses the relative amount (\%) of dissolved solids contained in a solution (Beckles, 2012). SSC is the total aggregate of sugars, acids, and additional microconstituents in the fruit pulp (Balibrea et al., 2006; Kader, 2008). SSC is a function of developmental 
control which is affected by fruit's genetic, physiological, and metabolic processes (Mounet et al., 2009; Wang et al., 2009). It has been reported that SSC tends to increase with an increase in ripeness (Özdemir et al., 2009; Vinha et al., 2013). SSC is a quality parameter which has a direct correlation with fruit maturity and ripening. The SSC increments during maturity and fruit ripening were reported to have been due to solubilization of polyuronides and hemicelluloses present in the cell wall (Huber, 1984; Nogataet al., 1993).

Furthermore, SSC has been determined destructively using refractometer but efforts have been made to quantify them using various non-destructive optical techniques such as Vis/NIR spectroscopy, multi and hyperspectral imaging system, and laser-induced backscattering imaging.

Knowledge of fruit optical properties is crucial to comprehending various processes happening within the fruit such processes as development, maturity, ripening, and senescence (Gorton et al., 2010). Optical properties of fruit can be employed to characterise the attributes of fruit as it is developing or ripening. Other than that, it is also essential in the assessment of fruit quality parameter. Optical methods which have found application in the determination of optical properties of fruit used visible to near-infrared spectrum of electromagnetic radiation (Nicolaïet al., 2007). This is because most of the fruit chemical composition such as chlorophyll, carotenoid, anthocyanins, water content etc absorbed photons at visible and near-infrared spectrum of electromagnetic radiation. This research investigated the use of laser backscattering imaging to evaluate quality parameters of pear fruit related to the development and classify into different maturity stages.

\section{Materials and methods}

\subsection{Sample collection and preparation}

Pears were collected from a commercial orchard located in Dürrweitzschen (Germany), starting from the end of July through to the end of September 2015. Sampling was done once a week for eight weeks beginning from $28^{\text {th }}$ July $-15^{\text {th }}$ September 2015 . The collected samples were stored at room temperature and the measurement of firmness and SSC was carried out. These measurements were carried out after the nondestructive measurements of the samples have been done using the LLBI system. A total of thirty pears were used for the measurements on each of the measurement days.

\subsection{Determination of pear $S S C$}

The SSC of the pear samples were determined using a refractometer. The sample was sliced across the equatorial section and juices were extracted from the cut sample. About two drops of the prepared juice were dropped onto the refractometer prism plate. Then the reading was taken to one decimal place. After the first measurement, the refractometer prism was cleaned with distilled water and tissue paper before taking the second measure for each of the samples. The average of the two measurements was recorded as SSC for that particular sample.

\subsection{Determination of pear firmness}

The pear firmness was determined destructively using a penetrometer. The sample peel of $2 \mathrm{~cm}^{2}$ from the opposite sides of the fruit was removed from the equatorial area. The prepared sample was held firmly with on the plate at the stand base of the penetrometer. The penetrometer was adjusted to zero and the plunger head was placed against the peeled area flesh of the fruit. Downward pressure was then applied until the plunger had penetrated halfway into the flesh of the peeled fruit. The plunger was removed and the reading was taken to one decimal place. This process was repeated for the opposite side of the fruit and the average of the two reading was recorded as the firmness of that fruit.

\subsection{Laser imaging}

The laser images of the pear fruits were captured using the imaging system developed and assembled at the Leibniz-Institute of Agricultural Engineering and Bioeconomy Potsdam-Bornim (ATB) Germany (Baranyai and Zude, 2009). The system setup consists of a CCD camera (CV-A50IR, JAI Ltd, Japan) with a zoom lens F2.5 and focal length 18-108 mm (12VG1040 ASIR -SQ, Tamron Co. Ltd, Japan), and a laptop for camera control, image capturing and storage. Five laser diodes of wavelength $(532,660,785,830$ and $1060 \mathrm{~nm})$ and power ratings $(10-85 \mathrm{~mW})$ were used to capture the images. The light was shone on the central area of the pear samples which were arranged facing up the CCG camera. The CCD camera captured a fraction of the backscattered light from the fruit surface and transferred it to the computer. To capture high quality images and reduced the noise capturing was done in the dark.

\subsection{Determination of optical property}

Optical properties (absorption and reduced scattering coefficients) were extracted from the backscattered images of pear fruit using Farrell's diffusion approximation equation built into LABVIEW software 
shown in equation 1.

$R_{f}\left(r, \mu_{a}, \mu_{s}^{\prime}\right)=\frac{a^{\prime}}{4 \pi}\left[\frac{1}{\mu_{t}^{\prime}}\left(\mu_{e f f}+\frac{1}{r_{1}}\right) \frac{\exp \left(-\mu_{e f f_{1}}\right)}{r_{1}^{2}}+\left(\frac{1}{\mu_{t}^{\prime}}+\frac{4 F}{3 \mu_{t}^{\prime}}\right)\left(\mu_{e f f}+\frac{1}{r_{2}}\right) \frac{\exp \left(-\mu_{e f f} r_{2}\right)}{r_{2}^{2}}\right]$

where;

$R_{f}=$ Diffuse reflectance,

$r=$ Distance from incident point,

$a^{\prime}=$ Transport albedo and is given as $a^{\prime}=\frac{\mu_{s}^{\prime}}{\mu_{a}+\mu_{s}^{\prime}}$

$\mu_{e f f}=$ Effective attenuation coefficient and is given as

$\mu_{e f f}=\left[3 \mu_{a}\left(\mu_{a}+\mu_{s}^{\prime}\right)\right]^{1 / 2}$

$\mu_{t}^{\prime}=$ Total attenuation coefficient and is given as

$\mu_{t}^{\prime}=\mu_{a}+\mu_{s}^{\prime}$

$\mu_{a}=$ Absorption coefficient

$\mu_{s}^{\prime}=$ Reduced scattering coefficient

The parameters $r_{1}$ and $r_{2}$ are computed using the following expression:

$$
\begin{aligned}
& r_{1}=\left[\left(\frac{1}{\mu_{t}^{\prime}}\right)^{2}+r^{2}\right]^{1 / 2} \\
& r_{2}=\left[\left(\frac{1}{\mu_{t}^{\prime}}+\frac{4 F}{3 \mu_{t}^{\prime}}\right)^{2}+r^{2}\right]^{1 / 2}
\end{aligned}
$$

(6) Since optical properties relate to fruit component and structure and these undergo significant changes during

(7) fruit development. Fruit components such as (8) anthocyanins, chlorophyll and water content absorbed light photon at a different wavelength and as the fruit

(9) develops the amount of these components either reduces or increases thereby alters the optical properties of the fruit. Likewise, as the fruit develops fruit softening sets in which invariably affect the fruit structures and the softening influence the optical properties. A different optical property was reported for flesh, seed-based and seed part of kiwifruit (Fang et al., 2015).

Table 2 shows that there is a strong correlation between absorption and reduced scattering coefficients with fruit development. There is a strong correlation

\begin{tabular}{|c|c|c|c|c|c|c|c|c|c|c|}
\hline \multirow{3}{*}{$\begin{array}{l}\text { Time } \\
\text { (dafb) }\end{array}$} & \multicolumn{10}{|c|}{ Wavelength (nm) } \\
\hline & \multicolumn{2}{|c|}{532} & \multicolumn{2}{|c|}{660} & \multicolumn{2}{|c|}{785} & \multicolumn{2}{|c|}{830} & \multicolumn{2}{|c|}{1060} \\
\hline & $\mu_{\mathrm{a}}{ }^{*}$ & $\mu_{\mathrm{s}}^{\prime *}$ & $\mu_{\mathrm{a}}$ & $\mu_{\mathrm{s}}^{\prime}$ & $\mu_{\mathrm{a}}$ & $\mu_{\mathrm{s}}^{\prime}$ & $\mu_{\mathrm{a}}$ & $\mu_{\mathrm{s}}^{\prime}$ & $\mu_{\mathrm{a}}$ & $\mu_{\mathrm{s}}^{\prime}$ \\
\hline 92 & $\begin{array}{c}0.089- \\
0.281\end{array}$ & $\begin{array}{c}4.405- \\
6.741\end{array}$ & $\begin{array}{c}0.008- \\
0.032\end{array}$ & $\begin{array}{c}1.262- \\
1.981\end{array}$ & $\begin{array}{c}0.008- \\
0.012\end{array}$ & $\begin{array}{c}2.113- \\
2.386\end{array}$ & $\begin{array}{c}0.002- \\
0.004\end{array}$ & $\begin{array}{c}1.336- \\
1.683\end{array}$ & $\begin{array}{c}0.002- \\
0.003\end{array}$ & $\begin{array}{c}1.278- \\
1.550\end{array}$ \\
\hline 99 & $\begin{array}{c}0.045- \\
0.308\end{array}$ & $\begin{array}{c}3.510- \\
6.779\end{array}$ & $\begin{array}{c}0.004- \\
0.029\end{array}$ & $\begin{array}{c}1.626- \\
3.167\end{array}$ & $\begin{array}{c}0.007- \\
0.013\end{array}$ & $\begin{array}{c}2.072- \\
2.431\end{array}$ & $\begin{array}{c}0.002- \\
0.005\end{array}$ & $\begin{array}{c}1.386- \\
1.724\end{array}$ & $\begin{array}{c}0.002- \\
0.004\end{array}$ & $\begin{array}{c}1.268- \\
1.533\end{array}$ \\
\hline 106 & $\begin{array}{c}0.071- \\
0.280\end{array}$ & $\begin{array}{c}4.173- \\
6.578\end{array}$ & $\begin{array}{c}0.005- \\
0.016\end{array}$ & $\begin{array}{c}1.833- \\
2.561\end{array}$ & $\begin{array}{c}0.005- \\
0.012\end{array}$ & $\begin{array}{c}1.847- \\
2.402\end{array}$ & $\begin{array}{c}0.002- \\
0.004\end{array}$ & $\begin{array}{c}1.318- \\
1.694\end{array}$ & $\begin{array}{c}0.002- \\
0.004\end{array}$ & $\begin{array}{c}1.272- \\
1.544\end{array}$ \\
\hline 113 & $\begin{array}{c}0.035- \\
0.267\end{array}$ & $\begin{array}{c}3.252- \\
6.522\end{array}$ & $\begin{array}{c}0.002- \\
0.013\end{array}$ & $\begin{array}{c}1.320- \\
2.379\end{array}$ & $\begin{array}{c}0.006- \\
0.010\end{array}$ & $\begin{array}{c}1.908- \\
2.245\end{array}$ & $\begin{array}{c}0.001- \\
0.003\end{array}$ & $\begin{array}{c}1.216- \\
1.534\end{array}$ & $\begin{array}{c}0.002- \\
0.003\end{array}$ & $\begin{array}{c}1.266- \\
1.484\end{array}$ \\
\hline 120 & $\begin{array}{c}0.031- \\
0.282\end{array}$ & $\begin{array}{c}3.160- \\
6.721\end{array}$ & $\begin{array}{c}0.003- \\
0.018\end{array}$ & $\begin{array}{c}1.452- \\
2.674\end{array}$ & $\begin{array}{c}0.007- \\
0.010\end{array}$ & $\begin{array}{c}1.982- \\
2.241\end{array}$ & $\begin{array}{c}0.001- \\
0.002\end{array}$ & $\begin{array}{c}1.299- \\
1.464\end{array}$ & $\begin{array}{c}0.002- \\
0.003\end{array}$ & $\begin{array}{c}1.314- \\
1.473\end{array}$ \\
\hline 127 & $\begin{array}{c}0.045- \\
0.173\end{array}$ & $\begin{array}{c}3.578- \\
5.733\end{array}$ & $\begin{array}{c}0.003- \\
0.017\end{array}$ & $\begin{array}{c}1.495- \\
2.590\end{array}$ & $\begin{array}{c}0.005- \\
0.009\end{array}$ & $\begin{array}{c}1.823- \\
2.129\end{array}$ & $\begin{array}{c}0.001- \\
0.002\end{array}$ & $\begin{array}{c}1.062- \\
1.386\end{array}$ & $\begin{array}{c}0.001- \\
0.003\end{array}$ & $\begin{array}{c}1.099- \\
1.470\end{array}$ \\
\hline 134 & $\begin{array}{c}0.042- \\
0.256\end{array}$ & $\begin{array}{c}3.484- \\
6.497\end{array}$ & $\begin{array}{c}0.003- \\
0.015\end{array}$ & $\begin{array}{c}1.486- \\
2.492\end{array}$ & $\begin{array}{c}0.006- \\
0.010\end{array}$ & $\begin{array}{c}1.881- \\
2.211\end{array}$ & $\begin{array}{c}0.001- \\
0.003\end{array}$ & $\begin{array}{c}1.149- \\
1.462\end{array}$ & $\begin{array}{c}0.002- \\
0.003\end{array}$ & $\begin{array}{c}1.216- \\
1.446\end{array}$ \\
\hline 141 & $\begin{array}{c}0.033- \\
0.194 \\
\end{array}$ & $\begin{array}{c}3.262- \\
5.824 \\
\end{array}$ & $\begin{array}{c}0.002- \\
0.011 \\
\end{array}$ & $\begin{array}{c}1.331- \\
2.228 \\
\end{array}$ & $\begin{array}{c}0.003- \\
0.009 \\
\end{array}$ & $\begin{array}{c}1.648- \\
2.171 \\
\end{array}$ & $\begin{array}{c}0.001- \\
0.003\end{array}$ & $\begin{array}{c}1.256- \\
1.481 \\
\end{array}$ & $\begin{array}{c}0.002- \\
0.004\end{array}$ & $\begin{array}{c}1.307- \\
1.537 \\
\end{array}$ \\
\hline
\end{tabular}

Table 1. Optical properties of pear from Farrell diffusion theory

$* \mu_{\mathrm{a}}$ and $\mu_{\mathrm{s}}^{\prime}$ in (a.u). 
Table 2. Correlation of Optical properties of pear from Farrell diffusion and reference measurements with days after full bloom at different wavelengths

\begin{tabular}{|c|c|c|c|c|c|c|}
\hline Wavelength (nm) & Parameter & $\mu_{\mathrm{a}}$ & $\mu_{\mathrm{s}}{ }^{\prime}$ & SSC & Firmness & Time (dafb) \\
\hline \multirow{5}{*}{532} & $\mu_{\mathrm{a}}$ & 1 & & & & \\
\hline & $\mu_{\mathrm{s}}{ }^{\prime}$ & 0.999 & 1 & & & \\
\hline & $\mathrm{SSC}$ & -0.964 & -0.972 & 1 & & \\
\hline & Firmness & 0.985 & 0.987 & -0.961 & 1 & \\
\hline & Time (dafb) & -0.958 & -0.962 & 0.975 & -0.966 & 1 \\
\hline \multirow{5}{*}{660} & $\mu_{\mathrm{a}}$ & 1 & & & & \\
\hline & $\mu_{\mathrm{s}}^{\prime}$ & 0.996 & 1 & & & \\
\hline & SSC & -0.89 & -0.904 & 1 & & \\
\hline & Firmness & 0.946 & 0.952 & -0.961 & 1 & \\
\hline & Time (dafb) & -0.89 & -0.901 & 0.975 & -0.966 & 1 \\
\hline \multirow{5}{*}{785} & $\mu_{\mathrm{a}}$ & 1 & & & & \\
\hline & $\mu_{\mathrm{s}}^{\prime}$ & 0.999 & 1 & & & \\
\hline & SSC & -0.908 & -0.914 & 1 & & \\
\hline & Firmness & 0.956 & 0.955 & -0.961 & 1 & \\
\hline & Time (dafb) & -0.894 & -0.897 & 0.975 & -0.966 & 1 \\
\hline \multirow{5}{*}{830} & $\mu_{\mathrm{a}}$ & 1 & & & & \\
\hline & $\mu_{\mathrm{s}}^{\prime}$ & 0.998 & 1 & & & \\
\hline & SSC & -0.877 & -0.88 & 1 & & \\
\hline & Firmness & 0.938 & 0.93 & -0.961 & 1 & \\
\hline & Time (dafb) & -0.854 & -0.847 & 0.975 & -0.966 & 1 \\
\hline \multirow{5}{*}{1060} & $\mu_{\mathrm{a}}$ & 1 & & & & \\
\hline & $\mu_{\mathrm{s}}{ }^{\prime}$ & 0.992 & 1 & & & \\
\hline & SSC & -0.524 & -0.569 & 1 & & \\
\hline & Firmness & 0.664 & 0.687 & -0.961 & 1 & \\
\hline & Time (dafb) & -0.545 & -0.57 & 0.975 & -0.966 & 1 \\
\hline
\end{tabular}

between the absorption and reduced scattering coefficient and this can be interpreted that both phenomena happen very strongly in pear sample with the system used. A downward trend correlation exists between absorption and reduced scattering coefficients and fruit development. This could be interpreted that as the fruit develops, the pigments such as anthocyanins, chlorophyll and water content responsible for absorption and fruit structural components such as cell wall undergo changes and these account for the downward trend observed with these properties with fruit development.

Table 3 shows that there is a moderate correlation between the optical properties of pear and the wavelengths used. It shows that there is a negative correlation between optical properties and the wavelength meaning that at lower wavelength more absorption and scattering occurs while less absorption and scattering occurs at a higher wavelength. That is components such as chlorophyll pigments and anthocyanins and others are absorbed in wavelengths 532 and $660 \mathrm{~nm}$ from previous studies (Phillips, 2006; Chang and Chang, 2014).

The results of the ANN predictions of the quality attributes of pear using absorption and reduced scattering coefficients at the individual wavelength and at combined wavelengths are as presented in Tables 4 The prediction of SSC and firmness parameters of pear are shown in Figures 1 and 2.

Table 3. Correlation of optical properties of pear extracted from Farrell diffusion with laser wavelength used

\begin{tabular}{lccc}
\hline & Wavelength $(\mathrm{nm})$ & $\mu_{\mathrm{a}}$ & $\mu_{\mathrm{s}}{ }^{\prime}$ \\
\hline Wavelength $(\mathrm{nm})$ & 1 & & \\
$\mu_{\mathrm{a}}$ & -0.671 & 1 & \\
$\mu_{\mathrm{s}}{ }^{\prime}$ & -0.783 & 0.966 & 1 \\
\hline
\end{tabular}

Table 4 reveals the prediction of SSC and firmness of pear when $\mu_{a}$ and $\mu_{s}^{\prime}$ are used at individual wavelength. The ANN prediction models show a high correlation coefficient at wavelengths 532, 660 and 830 $\mathrm{nm}$ which can be attributed to the presence of pigments that absorb light photon present in the pear fruit. It can be concluded that pigments played a very significant role when it comes to customers making the choice of purchase.

Table 5 shows that combined wavelengths, firmness predictions recorded higher correlation coefficients at three combined wavelengths of 532, 660 and $785 \mathrm{~nm}$. It has been reported that chlorophyll is absorbed in visible electromagnetic wavelength around 400-700 nm (Babar et al., 2006; Cozzolino et al., 2004; Zude et al., 2006). 
Table 4. Performance evaluation of the prediction models using pear $\mu_{\mathrm{a}}$ and $\mu_{\mathrm{s}}{ }^{\prime}$ from Farrell diffusion

\begin{tabular}{ccccccccc}
\hline Wavelength (nm) & Method & Parameter & RMSEC & $\mathrm{r}$ & bias & RMSECV & $\mathrm{r}$ & bias \\
\hline \multirow{2}{*}{532} & \multirow{2}{*}{ ANN (MLP) } & SSC & 1.117 & 0.667 & 0.003 & 1.089 & 0.808 & 0.139 \\
& & Firmness & 27.361 & 0.748 & 0.036 & 20.762 & 0.89 & 2.584 \\
\hline \multirow{2}{*}{660} & \multirow{2}{*}{ ANN (MLP) } & SSC & 1.14 & 0.652 & 0.069 & 1.077 & 0.813 & 0.144 \\
& & Firmness & 24.621 & 0.802 & 0.394 & 22.492 & 0.881 & 0.922 \\
\hline \multirow{2}{*}{785} & \multirow{2}{*}{ ANN (MLP) } & SSC & 1.113 & 0.67 & 0.001 & 1.077 & 0.818 & 0.116 \\
& & Firmness & 21.599 & 0.852 & 0.276 & 15.061 & 0.947 & 4.959 \\
\hline \multirow{2}{*}{830} & \multirow{2}{*}{ ANN (MLP) } & SSC & 1.148 & 0.643 & 0.013 & 1.115 & 0.808 & 0.061 \\
& & Firmness & 21.374 & 0.855 & 0.047 & 18.36 & 0.931 & 2.434 \\
\hline \multirow{2}{*}{1060} & \multirow{2}{*}{ ANN (MLP) } & SSC & 1.128 & 0.659 & 0.01 & 1.086 & 0.813 & 0.122 \\
& & Firmness & 28.801 & 0.716 & 0.467 & 25.047 & 0.848 & 3.406 \\
\hline
\end{tabular}
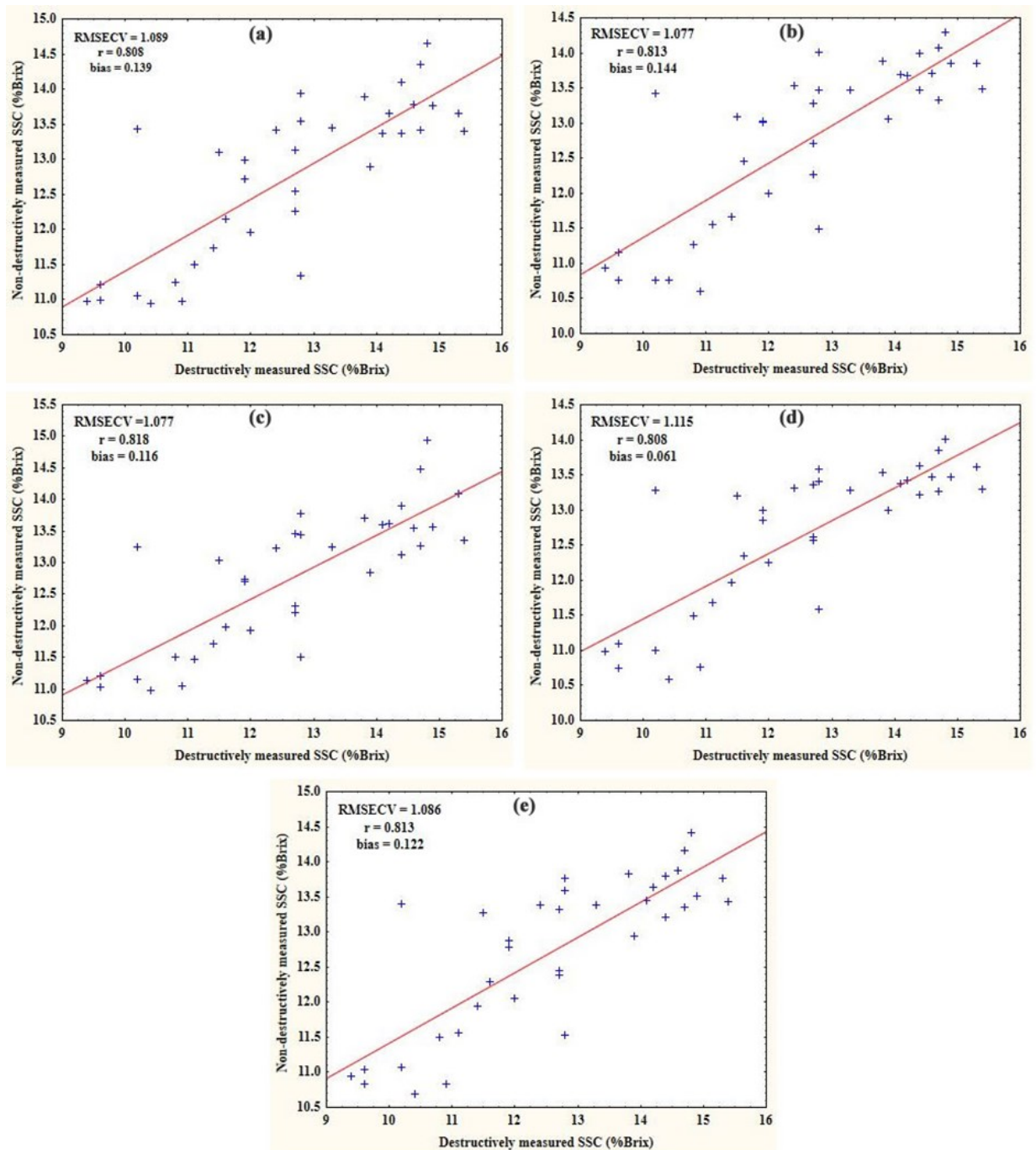

Figure 1. SSC prediction at different wavelength with pear absorption and reduced scattering coefficients from Farrell diffusion (a) $532 \mathrm{~nm}$ (b) $660 \mathrm{~nm}$ (c) $785 \mathrm{~nm}$ (d) $830 \mathrm{~nm}$ (e) $1060 \mathrm{~nm}$ with ANN model.

Table 5. Performance evaluation of the prediction models using $\mu_{a}$ and $\mu_{s}^{\prime}$ at combined wavelengths

\begin{tabular}{ccccccccc}
\hline Wavelength (nm) & Method & Parameter & RMSEC & $\mathrm{r}$ & bias & RMSECV & $\mathrm{r}$ & Bias \\
\hline \multirow{2}{*}{532,660} & \multirow{2}{*}{ ANN (MLP) } & SSC & 1.123 & 0.663 & 0.001 & 1.106 & 0.792 & 0.085 \\
& & Firmness & 25.932 & 0.777 & 0.314 & 23.523 & 0.86 & 3.582 \\
\hline \multirow{2}{*}{$532,660,785$} & \multirow{2}{*}{ ANN (MLP) } & SSC & 1.11 & 0.672 & 0.031 & 1.125 & 0.792 & 0.114 \\
& & Firmness & 19.326 & 0.883 & 0.07 & 16.887 & 0.942 & 2.066 \\
\hline \multirow{2}{*}{$532,660,785,830$} & \multirow{2}{*}{ ANN (MLP) } & SSC & 1.145 & 0.652 & 0.088 & 1.193 & 0.782 & 0.137 \\
& & Firmness & 19.702 & 0.878 & 0.503 & 17.733 & 0.933 & 1.764 \\
\hline $532,660,785$, & \multirow{2}{*}{ ANN (MLP) } & SSC & 1.127 & 0.659 & 0.01 & 1.138 & 0.777 & 0.122 \\
830,1060 & & Firmness & 17.33 & 0.907 & 0.25 & 19.545 & 0.919 & 2.716 \\
\hline
\end{tabular}



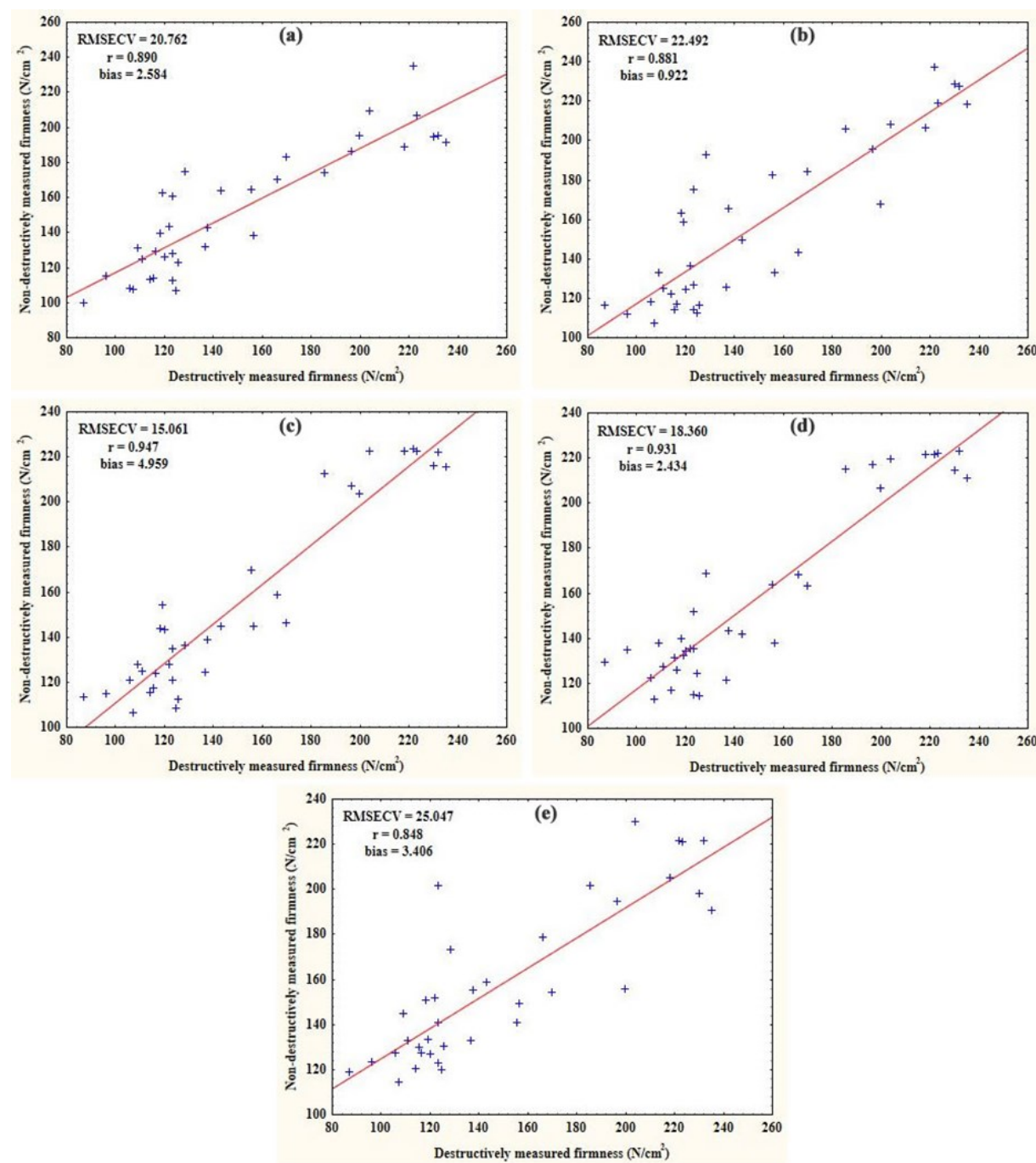

Figure 2. Firmness prediction at different wavelength with pear absorption and reduced scattering coefficients from Farrell diffusion (a) $532 \mathrm{~nm}$ (b) $660 \mathrm{~nm}$ (c) $785 \mathrm{~nm}$ (d) $830 \mathrm{~nm}$ (e) $1060 \mathrm{~nm}$ with ANN model.

Other pigments such as anthocyanin which is responsible for colour change as fruit ripens has been reported to be absorbed within the visible spectrum of electromagnetic radiation (Butz et al., 2005; Cubeddu et al., 2002). It is also revealed from the Table 5 that ANN models gave a higher correlation coefficient than when individual wavelength models for all the quality parameters of pears that were predicted when $\mu_{a}$ and $\mu_{s}{ }^{\prime}$ at combined wavelengths were used.

The classification of pear into different stages of development was done using absorption $\left(\mu_{a}\right)$ and reduced scattering $\left(\mu_{s}^{\prime}\right)$ coefficients at the individual wavelength and combine wavelength. Table 6 shows the overall classification accuracy at individual and at combine wavelengths. The table shows that the highest classification accuracy of $87.08 \%$ was achieved at combined wavelengths of three wavelengths of 532, 660 and $785 \mathrm{~nm}$ with ANN classifier. At individual wavelength, ANN recorded a range of between 80.42 and $86.67 \%$ with wavelength $785 \mathrm{~nm}$ recorded $86.67 \%$.
Table 6. Overall classification accuracy using pear $\mu_{a}$ and $\mu_{s}{ }^{\prime}$ from Farrell diffusion at individual and combined wavelength

\begin{tabular}{cc}
\hline \multirow{2}{*}{ Wavelength $(\mathrm{nm})$} & Method \\
\cline { 2 - 2 } & ANN \\
\hline 532 & 82.5 \\
660 & 82.08 \\
785 & 86.67 \\
830 & 85.42 \\
1060 & 80.42 \\
532,660 & 80.42 \\
$532,660,785$ & 87.08 \\
$532,660,785,830$ & 83.75 \\
$532,660,785,830,1060$ & 86.67 \\
\hline
\end{tabular}

\section{Conclusion}

Fruit quality is composed of many characteristics or attributes such as sensory, chemical, physical, nutritive, mechanical, functional and defects attributes. To evaluate these qualities, there is a need to quantify quality-dependent attributes or parameters such as SSC, firmness, elasticity, chlorophyll etc. Quantification of these parameters have been done using various instruments which are in most cases destructive, resulting in fewer samples being tested and this does not 
take into cognizance the variation existing between the fruit lot. In order to overcome this challenge, nondestructive methods of quality evaluation have been receiving alloyed attention from the countless number of researchers. With many focusing on the non-destructive optical methods. Laser light backscattering imaging system is one of such techniques. The results showed that the SSC of pear increase as the fruits matures. A range of 9.2 to $17.2 \%$ Brix SSC was obtained from 92 to $141 \mathrm{dafb}$ while 85.5 to $264.2 \mathrm{~N} / \mathrm{cm}^{2}$ was the range of firmness obtained during the period of monitoring pear maturity. The optical properties of the fruit show a very strong correlation with days after the full bloom of the fruit therefore the properties can be used to monitor the pear fruit development.

\section{Acknowledgement}

The authors would like to acknowledge the technical and financial supports from Prof. Manuela Zude and Christian Regen of the Department of Horticultural Engineering, Leibniz Institute for Agricultural Engineering and Bioeconomy (ATB) 14469 PotsdamBornim, Germany. The authors are equally grateful for the financial support received from the Ministry of Science, Technology and Innovation, 386 Malaysia under a Science fund research grant (Vot number: 5450728).

\section{References}

Babar, M.A., Reynolds, M.P., Van Ginkel, M., Klatt, A.R., Raun, W.R. and Stone, M.L. (2006). Spectral reflectance to estimate genetic variation for inseason biomass, leaf chlorophyll and canopy temperature in wheat. Crop Science, 46(3), 10461057. https://doi.org/10.2135/cropsci2005.0211

Balibrea, M.E., Martínez-Andújar, C., Cuartero, J., Bolarín, M.C. and Pérez-Alfocea, F. (2006). The high fruit soluble sugar content in wild Lycopersicon species and their hybrids with cultivars depends on sucrose import during ripening rather than on sucrose metabolism. Functional Plant Biology, 33 (3), 279-288. https://doi.org/10.1071/FP05134

Baranyai, L. and Zude, M. (2009). Analysis of laser light propagation in kiwifruit using backscattering imaging and Monte Carlo simulation. Computers and Electronics in Agriculture, 69(1), 33-39. https:// doi.org/10.1016/j.compag.2009.06.011

Beckles, D.M. (2012). Factors affecting the postharvest soluble solids and sugar content of tomato (Solanum lycopersicum L.) fruit. Postharvest Biology and Technology, 63(1), 129-140. https://doi.org/10.1016/ j.postharvbio.2011.05.016
Butz, P., Hofmann, C. and Tauscher, B. (2005). Recent developments in non invasive techniques for fresh fruit and vegetable internal quality analysis. Journal of Food Science, 70(9), 131-141. https:// doi.org/10.1111/j.1365-2621.2005.tb08328.x

Chang, C.L. and Chang, K.P. (2014). The growth response of leaf lettuce at different stages to multiple wavelength-band light-emitting diode lighting. Scientia Horticulturae, 179, 78-84. https:// doi.org/10.1016/j.scienta.2014.09.013

Cozzolino, D., Esler, M.B., Dambergs, R.G., Cynkar, W.U., Boehm, D.R., Francis, I.L. and Gishen, M. (2004). Prediction of colour and $\mathrm{pH}$ in grapes using a diode array spectrophotometer (400-1100 nm). Journal of Near Infrared Spectroscopy, 12(2), 105112. https://doi.org/10.1255/jnirs.414

Cubeddu, R., Pifferi, A., Taroni, P. and Torricelli, A. (2002). Measuring fresh fruit and vegetable quality: advanced optical methods. Fruit and Vegetable Processing-Improving Quality, p. 150-169. Boca Raton: CRC Press/Woodhead Publishing Limited. https://doi.org/10.1533/9781855736641.2.150

Fang, Z.H., Fu, X.P. and He, X.M. (2015). Investigation of absorption and scattering characteristics of kiwifruit tissue using a single integrating sphere system. Journal of Zhejiang University Science B, 17 (6), 484-492. https://doi.org/10.1631/jzus.B1500086

Farrell, T.J., Patterson, M.S. and Wilson, B. (1992). A diffusion theory model of spatially resolved, steady state diffuse reflectance for the non invasive determination of tissue optical properties in vivo. Medical Physics, 19(4), 879-888. https:// doi.org/10.1118/1.596777

Foody, G.M. (2004). Supervised image classification by MLP and RBF neural networks with and without an exhaustively defined set of classes. International Journal of Remote Sensing, 25(15), 3091-3104. https://doi.org/10.1080/01431160310001648019

Gorton, H.L., Brodersen, C.R., Williams, W.E. and Vogelmann, T.C. (2010). Measurement of the optical properties of leaves under diffuse light. Photochemistry and Photobiology, 86(5), 1076$1083 . \quad$ https://doi.org/10.1111/j.17511097.2010.00761.x

Hoehn, E., Gasser, F., Guggenbühl, B. and Künsch, U. (2003). Efficacy of instrumental measurements for determination of minimum requirements of firmness, soluble solids and acidity of several apple varieties in comparison to consumer expectations. Postharvest Biology and Technology, 27(1), 27-37. https:// doi.org/10.1016/S0925-5214(02)00190-4

Huber, D. (1984). Strawberry fruit softening: the 
potential roles of polyuronides and hemicelluloses. Journal of Food Science, 49(5), 1310-1315. https:// doi.org/10.1111/j.1365-2621.1984.tb14976.x

Kader, A.A. (2008). Flavor quality of fruits and vegetables. Journal of the Science of Food and Agriculture, 88(11), 1863-1868. https:// doi.org/10.1002/jsfa.3293

Liu, Y., Sun, X. and Ouyang, A. (2010). Non destructive measurement of soluble solid content of navel orange fruit by visible-NIR spectrometric technique with PLSR and PCA-BPNN. LWT-Food Science and Technology, 43(4), 602-607. https://doi.org/10.1016/ j.lwt.2009.10.008

Mounet, F., Moing, A., Garcia, V., Petit, J., Maucourt, M., Deborde, C., Bernillon, S., Le Gall, G., Colquhoun, I. and Defernez, M. (2009). Gene and metabolite regulatory network analysis of early developing fruit tissues highlights new candidate genes for the control of tomato fruit composition and development. Plant Physiology, 149(3), 1505-1528. https://doi.org/10.1104/pp.108.133967

Nicolaï, B.M., Beullens, K., Bobelyn, E., Peirs, A., Saeys, W., Theron, K.I. and Lammertyn, J. (2007). Nondestructive measurement of fruit and vegetable quality by means of NIR spectroscopy: A review. Postharvest Biology and Technology, 46(2), 99-118. https://doi.org/10.1016/j.postharvbio.2007.06.024

Nogata, Y., Ohta, H. and Voragen, A. (1993). Polygalacturonase in strawberry fruit. Phytochemistry, 34(3), 617-620. https:// doi.org/10.1016/0031-9422(93)85327-N

Özdemir, A.E., Candir, E.E., Toplu, C., Kaplankiran, M., Demirkeser, T.H. and Yildiz, E. (2009). The effects of physical and chemical changes on the optimum harvest maturity in some avocado cultivars. African Journal of Biotechnology, 8(9), 104-116.

Phillips, T.A. (2006). Spectral Reflectance Imagery and Baseline Analysis of Anthocyanin Concentration in Gossypium Hirsutum L. South Dakota, USA: Dakota Wesleyan University, PhD. Dissertation.

Vinha, A.F., Moreira, J. and Barreira, S.V. (2013). Physicochemical Parameters, Phytochemical Composition and Antioxidant Activity of the Algarvian Avocado (Persea americana Mill.). Journal of Agricultural Science, 5(12), 100-105. https://doi.org/10.5539/jas.v5n12p100

Wang, H., Schauer, N., Usadel, B., Frasse, P., Zouine, M., Hernould, M., Latché, A., Pech, J.-C., Fernie, A.R. and Bouzayen, M. (2009). Regulatory features underlying pollination-dependent and-independent tomato fruit set revealed by transcript and primary metabolite profiling. The Plant Cell, 21(5), 1428-
1452. https://doi.org/10.1105/tpc. 108.060830

Wold, A.B., Rosenfeld, H.J., Holte, K., Baugerød, H., Blomhoff, R. and Haffner, K. (2004). Colour of postharvest ripened and vine ripened tomatoes (Lycopersicon esculentum Mill.) as related to total antioxidant capacity and chemical composition. International Journal of Food Science and Technology, 39(3), 295-302. https://doi.org/10.1111/ j.1365-2621.2004.00784.x

Zude, M., Herold, B., Roger, J.-M., Bellon-Maurel, V. and Landahl, S. (2006). Non-destructive tests on the prediction of apple fruit flesh firmness and soluble solids content on tree and in shelf life. Journal of Food Engineering, 77(2), 254-260. https:// doi.org/10.1016/j.jfoodeng.2005.06.027 